\title{
Teori- teori Belajar untuk Kecerdasan Bahasa Anak Usia Dini
}

\section{Margaretha ${ }^{1, a)}$} Affiliation:

1. Program Studi Pendidikan Guru PAUD FKIP UNIVED

Bengkulu

Corresponding Author:

argarethalydia@gmail.com

\section{Abstract}

Learning theory raised by educational psychologists after they have difficulty to explain the whole learning process Implementation of Early Childhood Education at this time can not be separated from the theories presented by experts, both psychologists, philosophers, and observers of education. These theories greatly assist teachers today in dealing with the Early Childhood, the methods to do to teach children, and how to deal with children and their behaviors. On the above issues, the purpose of this paper is: Knowing what Tiori is used in the implementation of language education in children in early childhood Dahlia Kota Bengkulu.The method used a qualitative method. Research location in Early Childhood Dahlia Kota Bengkulu. Data collection using interviews, observation, and documentation. Research results show: Theory learning that is used in Early Childhood Dahlia integrated in every material, But Learning Theory for language intelligence in processing Words become a mainstay in educating children in early childhood Dahlia Bengkulu City.

Keyword: Theory Learning, Language Intelligence, Early Childhood 


\section{Pendahuluan}

Teori belajar merupakan upaya untuk mendeskripsikan bagaimana manusia belajar, sehingga membantu kita semua memahami proses yang kompleks dari belajar Tugas guru tidak hanya menyampaikan informasi kepada peserta didik, tetapi harus menjadi fasilitator yang bertugas memberikan kemudahan belajar (facilitate of learning) kepada seluruh peserta didik. Agar dapat melakukan proses pembelajaran ini seorang guru harus bisa menyiapkan pembelajarannya. Untuk menjadi motivator yang baik guru harus berupaya dengan optimal mempersiapkan rancangan pembelajaran yang sesuai dengan karakteristik anak didik, demi mencapai tujuan pembelajaran..

Teori belajar dimunculkan oleh para psikolog pendidikan setelah mereka mengalami kesulitan untuk menjelaskan proses belajar secara menyeluruh. Sebagian psikolog menghaluskan kesulitan ini dengan istilah : memperjelas pengertian dan proses belajar (Mahmud, 2009). Belajar merupakan proses dimana seseorang dari tidak tahu menjadi tahu. Proses belajar ini dimulai sejak manusia masih bayi sampai sepanjang hayatnya. Kapasitas manusia untuk belajar merupakan karakteristik penting yang membedakan manusia dari makhluk hidup lainnya. Kajian tentang kapasitas manusia untuk belajar, terutama tentang bagaimana proses belajar terjadi pada manusia mempunyai sejarah panjang dan telah menghasilkan beragam teori. Teori belajar diartikan sebagai integrasi yang menuntun di dalam merancang kondisi demi tercapainya tujuan pendidikan. Oleh karena itu dengan adanya teori belajar akan memberikan kemudahan bagi guru dalam menjalankan modelmodel pembelajaran yang akan dilaksanakan. Tanpa bahasa seseorang tidak akan dapat berkomunikasi dengan orang lain. Komunikasi antar anak dapat terjalin dengan baik dengan bahasa sehingga anak dapat membangun hubungan sehingga tidak mengherankan bahwa bahasa dianggap sebagai salah satu indikator kesuksesan seorang anak. Sebelum dia belajar pengetahuan-pengetahuan lain, dia perlu menggunakan bahasa agar dapat memahami dengan baik. PAUD (Pendidikan anak usia dini) Dahlia merupakan lembaga pendidikan kelompok bermain yang ditujukan bagi anak-anak usia dini untuk melaksanakan suatu proses pengenalan pembelajaran agar anak dapat berkembang secara wajar sebagai seoranganak. Lembaga pendidikan prasekolah ini ditujukan untuk membantu memberikan stimulasi pada anak usia dini khususnya dimasa keemasan mereka dan juga sebagai dasar pembentukan sikap, perilaku, pengetahuan, keterampilan, daya pikir, dan daya cipta. Pada PAUD Dahlia ini pola yang diterapkan dalam memberikan pendidikan Bahasa dalam mengolah kata-katayaitu melalui pembiasaan, permainan, bercerita, dan tidak lupa peran dari orang tua tidak di tekankan.Penerapan pendidikanBahasa ini diharapkan dapat menjadikan anak berperilaku baik dan memiliki kepribadian yang terpuji sehingga terbiasa dengan melakukan hal-hal baik pada kehidupan seharihari hingga akhir hayatnya.

Berdasarkan uraian yang telah dijelaskan di atas, peneliti tertarik untuk melakukan penelitian kualitatif dengan judul Tiori-Tiori Belajar Untuk Kecerdasan Bahasa Anak Usia Dini. Perumusan masalah dalam penelitian ini, diuraikan dengan bagian-bagian identifikasi, kemudian batasan masalah, dan terakhir rumusan masalah pada yang permasalahan yang lebih spesifik dan penelitian. Berdasarkan rumusan masalah di atas maka penelitian ini bertujuan untuk Mengetahui: Mengetahui Tiori belajar apa yang digunakan dalam pelaksanaan Pendidikan Bahasa anak di PAUD Dahlia Kota Bengkulu. Sebagai mana di atas Pendidikan Bahasa salam mengolah kata adalah proses pemberian tuntunan kepada peserta didik untuk menjadi manusia yang dapat berbicara dengan santun. Sementara Suryani berpendapat (dalamWibowo,2013) usia dini adalah fase yang dinilai dari usia 0 tahun sampai anak berusia sekitar 6 tahun. Ditinjau dari usia kronologis UNESCO mengelompokkan anak usia dini berada pada rentang usia 0-8 tahun. Rentang usia anak dini yang dijadikan dalam bahan penelitian ini adalah anak usia dini yang berusia 0-6 tahun, seperti yang dijelaskan dan diatur dalam UU Sisdiknas no.20 tahun 2003 pasal 28 ayat 1

Di Indonesia rentang anak usia dini menurut Undang-undang Sisdiknas no. 20 tahun 2003 pasal 28 ayat 1 adalah anak dengan usia 0-6 tahun. Sehingga anak ang telah berusia diatas 6 tahun sudah berada pada jalur pendidikan dasar (primary school) (Damayanti,2011). Rentang usia anak dini yang dijadikan dalam bahan penelitian ini adalah anak usia dini yang berusia 0-6 tahun, seperti yang dijelaskan dan diatur dalam UU Sisdiknas no.20 tahun 2003 pasal 28 ayat 1. Pada masa ini, anak harus dapat 
menunjukkan sikap mulai lepas dari ikatan orang tua, anak harus dapat bergerak bebas dan berinteraksi dengan lingkungannya. Kondisi lepas dari orang tua menimbulkan ras untuk berinisiatif sebaliknya menimbulkan rasa bersalah. Anak harus dapat melaksanakan tugas-tugas perkembangan untuk menyiapkan diri memasuki masa dewasa. Perlu memiliki suatu keterampilan tertentu. Bila anak mampu menguasai keterampilan tertentu dapat menimbulkan rasa berhasil, sebaliknya bila tidak menguasai, menimbulkan rasa rendah diri.

\section{Metode Penelitian}

Penelitian ini di lakukan di PAUD Dahlia beralamatkan jalan Pepaya RT 11. RW 4 perumnas Lingkar timur Kota Bengkulu. Penelitian ini menggunakan penelitian kualitatif. Penelitian kualitatif adalah penelitian yang menghasilkan prosedur analisis yang tidak menggunakan prosedur analisis statisktik atau cara kuatifikasi lainnya (Moleong, 2009). sehingga untuk mengumpulkan data yang tepat dengan menggunakan metode sebagai berikut:(1). Pengamatan ( Observasi),(2) Wawancara ( Interview), (3) Dokumentasi . Salah satu alasan menggunakan pendekatan kualitatif adalah pengalaman para peneliti dimana metode ini dapat digunakan untuk menemukan dan memahami apa yang tersembunyi dibalik fenomena yang seringkali merupakan sesuatuyang sulit untuk dipahami secara mamuaskan Penulis mengambil lokasi di PAUD Dahlia karena sudah memasukkan nilai-nilai pembentuk karakter yang menjadi prioritas dan sudah menggunakan acuan Peraturan Menteri Pendidikan Nasional No. 58 tahun 2009 tentang Standar Pendidikan Anak Usia Dini. Dalam penelitian ini yang menjadi fokus penelitian adalah: Tiori belajar yang digunakan di PAUD Dahlia terintegrasi dalam setiap materi, Namun Teori untuk kecerdasan bahasa dalam mengolah Kata -kata tidak menjadi andalan dalam mendidik anakdi PAUD Dahlia Kota Bengkulu

Sumber Data Penelitian ini yaitu :

a. Sumber data Primer

Data primer adalah kata-kata atau tindakan orang-orang yang diamati atau diwawancarai, (Moleong, 2009). Data primer merupakan sumber data yang diperoleh secara langsung melalui wawancara dengan subjek penelitian dilapangan. Sumber data primer dalam penelitian ini adalah kepala sekolah, guru, peserta didik dan juga orang tua dari peserta didik di PAUD Dahlia Kota Bengkulu.

b. Sumber data Sekunder

Data sekunder ini diperoleh dari sumber tertulis, yaitu bersumber dari buku-buku atau literartur yang berkaitan dengan judul dan tema dari penelitian ini yaitu tentang pendidikan Bahasa pada anak usiadini.

Teknik keabsahan data dalam penelitian ini dalah menggunakan teknik triangulasi. Triangulasi adalah teknik pemeriksaan keabsahan data yang memanfaatkan sesuatu yang lain diluar data itu untuk keperluan pengecekan atau teknik pemeriksaan data ini memanfaatkan sesuatuy ang lain untuk keperluan pengecekan atau membandingkan. Seiddel (dalam Moleong, 2009) menjelaskan proses jalannya analisis data kualitatif adalah sebagai berikut:

a. Mencatat hasil lapangan, dengan hal itu diberikan oleh nara sumber datanya tetap dapat ditelusuri.

b. Mengumpulkan, memilah-milah, mengklasifikasikan, mensintesiskan, membuat ikhtisar, dan membuat indeksnya.

c. Berpikir, dengan jalan membuat agar kategori data itu mempunyai makna, mencari dan menemukan poladan hubungan-hubungan, dan membuat temuan-temuan umum.

Selanjutnya Rachman menjelaskan (2011) proses analisis data dilakukan sejak sebelum memasuki lapangan, selama dilapangan, dan setelah selesai dari lapangan. Analisis data sebelum peneliti memasuki lapangan dilakukan terhadap data pendahuluan atauyang disebu tdengan data sekunder yang digunakan sebagai penentu fokus penelitian, dimana fokus penelitian tersebut masih bersifat sementara dan dapat berkembang setelah dilakukan penelitian dan selama di lapangan. Analisis data dilakukan pada saat pengumpulan data sedang dilaksanakan, dan setelah selelsai pengumpulan data dalam waktu tertentu. Aktivitas menganalisis dilakukan secara interaktif dan berlangsung secara terus menerus sampai tuntas, sehingga data yang diperoleh sudah jenuh. Aktivitas dalam analisis data antara lain Reduksi data (data reduction), Penyajian data (datadisplay), dan Penarikan kesimpulan dan verifikasi (conclusion drawing/verification) (Miles dan Huberman, 1992). 


\section{Hasil dan Pembahasan}

Pendidikan Bahasa terhadap anak PAUD Dahlia disesuaikan dengan fase usianya, hal itu dilakukan karena sifat alamiah yang dimiliki oleh seorang anak dan memudahkan pendidik dalam menanamkan cara berbahasa sesuai dengan porsinya Untuk itu mengenalkan Bahasa pada anak usia dini harus disesuaikan dengan porsinya tidak melebihi ataupun mengurangi apa yang seharusnya diajarkan. Mengajarkan bahasa sejak dini akan memudahkan bagi anak karena masa ini merupakan suatu periode yang sangat menakjubkan dimana terjadi pertumbuhan kosa kata yang sangat cepat bagi anak.

Adapun Strategi Guru PAUD Dahlia dalam Pendidikan Bahasa anak melalui melalui berbagai Tiori di antaranya adalah

Teori behaviorist

Teori Nativist

Teori Constructive

\section{Pengertian Teori Belajar}

Teori adalah seperangkat asas tentang kejadian-kejadian yang didalamnnya memuat ide, konsep, prosedur dan prinsip yang dapat dipelajari, dianalisis dan diuji kebenarannya. Belajar merupakan kegiatan yang sering dilakukan setiap orang. Belajar dilakukan hampir setiap waktu, kapan saja, dimana saja, dan sedang melakukan apa saja. Belajar juga merupakan aktivitas yang dilakukan seseorang untuk mendapatkan perubahahan dalam dirinya melalui pelatihan-pelatihan atau pengalaman-pengalaman. Belajar dapat membawa perubahan pada si pelaku, baik perubahan pengetahuan, sikap, maupun ketrampilan ( Harudin, 2010) Pengertian belajar sendiri adalah suatu perubahan dalam tingkah laku dan penampilan sebagai hasil dari praktik dan pengalaman.

Jadi teori belajar adalah sebuah konsep yang abstrak yang membantu peserta didik untuk belajar.

\section{Macam-macam Teori Belajar}

Di dalam masa perkembangan psikologi pendidikan ini muncullah beberapa aliran psikologi pendidikan, diantaranya yaitu :Ada beberapa teori yang merupakan implementasi berbahasa antara lain:

a. Teori behaviorist b. Teori Nativist

c. Teori Constructive

a.Teori behaviorist

1) Pengertian Tiori Behavioristik.

Teori belajar behavioristik ini dikenal dengan sebuah teori yang dicetuskan oleh Gage dan Berliner tentang perubahan tingkah laku sebagai hasil dari pengalaman.( Gage\& Berliner,1979). Seseorang dianggap telah melakukan belajar sesuatu jika menunjukkan perubahan tingkah lakunya. ( Budiningsih, 2005). Misalnya; siswa belum dapat dikatakan berhasil dalam belajar Ilmu Pengetahuan Sosial jika dia belum bisa/tidak mau melibatkan diri dalam kegiatan-kegiatan sosial seperti; kerja bakti, ronda dll.

Menurut teori ini yang terpenting adalah :

a) Masukan atau input yang berupa stimulus dan keluaran atau output yang berupa respons.

Stimulus adalah apa saja yang diberikan guru kepada siswa misalnya alat perkalian, alat peraga, pedoman kerja atau cara-cara tertentu untuk membantu belajar siswa, sedangkan respon adalah reaksi atau tanggapan siswa terhadap stimulus yang diberikan guru tersebut. Teori ini juga mengutamakan pengukuran, sebab pengukuran merupakan suatu hal yang penting untuk melihat terjadi tidaknya perubahan tingkah laku tersebut.

b) Penguatan (reinforcement)

Penguatan yaitu sesuatu yang dapat memperkuat timbulnya respon. Misalnya, ketika peserta didik diberi tugas oleh guru, ketika tugasnya ditambahkan maka ia akan semakin giat belajarnya, maka penambahan tugas tersebut merupakan penguatan positif dalam belajar, begitu juga sebaliknya.

c) Tokoh-Tokoh dan Pemikirannya terhadap Teori Belajar Behavioristik.

(1) Thorndike : koneksionisme.

Thorndike adalah seorang pendidik, psikolog dari Amerika. Menurutnya, belajar merupakan proses interaksi antara Stimulus (S) yang mungkin berupa pikiran, perasaan atau gerakan dan Respon (R) yang juga berupa pikiran, perasaan atau gerakan. Dari 
percobaannya yang terkenal (puzzle box) diketahui bahwa supaya tercapai hubungan antara stimulus dan respon, perlu adanya kemampuan untuk memilih respon yang tepat serta melalui usaha-usaha atau percobaanpercobaan (trial) dan kegagalan-kegagalan (Error) terlebih dahulu. Edward L. Thorndike dalam teori connectionism dari Amerika Serikat, menyatakan bahwa dasar dari belajar adalah asosiasi antara kesan panca indera dan inplus untuk bertindak atau terjadinya hubungan antara stimulus dan respon disebut Bond, sehingga dikenal dengan teori $\mathrm{S}-\mathrm{R}$ Bond. Watson : Conditioning Watson mendefinisikan belajar sebagai proses interaksi antara stimulus dan respon, namun stimulus dan respon yang dimaksud harus dapat di amati (observable) dan dapat di ukur. Jadi meskipun dia mengakui adanya perubahan-perubahan mental dalam diri seseorang selama proses belajar, namun dia menganggap faktor tersebut sebagai hal yang tidak perlu di perhitungkan karena tidak dapat diamati. Watson adalah seorang behaviorist murni, karena kajianya tentang belajar disejajarkan dengan ilmu-ilmu lain seperti fisika atau biologi yang sangat berorientasi pada pengalaman empirik semata, yaitu sejauh mana dapat diamati dan diukur. Hanya dengan asumsi seperti itulah - menurut watson - kita dapat meramalkan perubahan apa yang bakal terjadi pada siswa.

(2) Edwin Guthrie :Conditioning.

Azas belajar guthrie yang utama adalah hukum kontinguity. Yaitu gabungan stimulus yang disertai suatu gerakan, pada waktu timbul kembali cenderung akan diikuti oleh gerakan yang sama. Guthrie juga menggunakan variabel hubungan stimulus respon untuk menjelaskan terjadinya proses belajar. Penguatan hanya sekedar melindungi hasil belajar yang baru agar tidak hilang dengan jalan mencegah perolehan respon yang baru. Teori guthrie ini mengatakan bahwa hubungan stimulus dan respon bersifat sementara, oleh karenanya dalam kegiatan belajar, peserta didik perlu sesering mungkin diberi stimulus agar hubungan stumulus dan respon bersifat lebih kuat dan menetap.

(3) Skinner : Operant conditioning

Skinner adalah seorang yang berkebangsaan Amerika yang dikenal sebagai seorang tokoh behavioris yang meyakini bahwa perilaku individu dikontrol melalui proses operant conditioning dimana seseorang dapat mengontrol tingkah laku organisme melalui pemberian reinforcement yang bijaksana dalam lingkungan yang relatif besar. Menagement kelas menurut skinner adalah berupa usaha untuk memodifikasi perilaku antara lain dengan proses penguatan yaitu memberi penghargaan pada perilaku yang diinginkan dan tidak memberi imbalan apapun pada perilaku yang tidak tepat. Teori belajar behavioristik ini telah lama dianut oleh para guru dan pendidik, namun dari semua pendukuung teori ini, teori Skinnerlah yang paling besar pengaruhnya terhadap perkembangan teori belajar Behavioristik. Program-program pembelajaran seperti Teaching Machine, pembelajaran berprogram, modul dan program-program pembelajaran lain yang berpijak pada konsep hubungan stimulus-respons serta mementingkan faktor-fktor penguat merupakan program-program pembelajaran yang menerapkan teori belajar yang dikemukakan oleh skinner.(Asri, 2005).

Menurut skinner - berdasarkan percobaanya terhadap tikus juga burung merpati - unsur terpenting dalam belajar yaitu penguatan. Maksudnya adalah penguatan yang terbentuk melalui ikatan stimulus respond akan semakin kuat bila diberi penguatan ( penguatan positif dan penguatan negatif). Bentuk penguatan positif adalah hadiah, perilaku, atau penghargaan. Sedangkan bentuk penguatan negatif adalah antara lain menunda atau tidak memberi penghargaan, memberikan tugas tambahan, atau menunjukkan perilaku tidak senang.

Skinner tidak percaya pada asumsi yang dikemukakan guthrie bahwa hukuman memegang peranan penting dalam proses 
pelajar. Hal tersebut dikarenakan menurut skinner :

a. Pengaruh hukuman terhadap perubahan tingkah laku sangat bersifat sementara

b. Dampak psikologis yang buruk mungkin akan terkondisi (menjadi bagian dari jiwa terhukum) bila hukuman berlangsung lama

c. Hukuman mendorong si terhukum mencari cara lain (meskipun salah dan buruk) agar ia terbebas dari hukuman

d. Hukuman dapat mendorong si terhukum melakukan hal-hal lain yang kadangkala lebih buruk dari pada kesalahan pertama yang diperbuatnya. Skinner lebih percaya dengan apa yang disebut penguatan baik negatif maupun positif.

(4) Pavlov: Classic Conditioning

Dalam pemikiranya Pavlov berasumsi bahwa dengan menggunakan rangsanganrangsangan tertentu, perilaku manusia dapat berubah sesuai dengan apa yang diinginkan. Berangkat dari asumsi tersebut Pavlov mengadakan eksperimen dengan menggunakan binatang (anjing) karena ia menganggap binatang memiliki kesamaan dengan manusia. Namun demikian, dengan segala kelebihanya secara hakiki, manusia berbeda dengan binatang. Pavlov mengadakan percobaan dengan cara mengadakan operasi leher pada seekor anjing. Sehingga keluar kelenjar air liurnya dari luar. Apabila diperlihatkan makanan, maka akan keluar air liur anjing tersebut. Ternyata kalau perbuatan yang demikian dilakukan berulangulang, rangsangan buatan ini akan menimbulkan syarat (kondisi) untuk timbulnya air liur pada anjing tersebut. ( Calvin \&Gardner, 1993 ).

2) Aplikasi teori behavioristik dalam pembelajaran.

Aplikasi teori behavioristik pada kegiatan pembelajaran yaitu karena melihat pengetahuan adalah objektif, pasti, tetap dan tidak berubah pengetahuan disusun dengan rapi sehingga belajar adalah perolehan pengetahuan, sedangkan mengajar adalah memindahkan pengetahuan (transfer of knowladge) kepada orang yang belajar. Fungsi pikiran adalah untuk menjiplak struktur pengetahuan yang sudah ada melalui proses berfikir yang dapat dianalisis dan dipilih, sehingga makna yang dihasilkan dari proses berfikir seperti ini ditentukan oleh karakteristik struktur pengetahuan tersebut. Belajar merupakan akibat adanya interaksi antara stimulus dan respon. Aliran psikologi belajar yang sangat besar pengaruhnya pada arah pengembangan teori dan praktik pendidikan dan pembelajaran hingga kini adalah aliran behavioristik.

3) Tujuan Pembelajaran Behaviorism

Tujuan pembelajaran menurut teori behavioristik ditekankan pada penambahan pengetahuan, sedangkan belajar sebagai aktivitas mimetic, yang menuntut pembelajar untuk mengungkapkan kembali pengetahuan yang sudah dipelajari dalam bentuk laporan, kuis, atau tes.

Beberapa prinsip Skinner:

a. Hasil belajar harus diberitahukan kepada siswa, jika salah dibetulkan dan jika benar diberi penguat.

b. Proses belajar harus mengikuti irama dari yang belajar.

c. Materi pelajaran, digunakan sistem modul.

d. Dalam proses pembelajaran, tidak digunkan hukuman.

e. Dalam proses pembelajaran, dipentingkan aktifitas sendiri.

f. Tingkah laku yang diinginkan pendidik, diberi hadiah, dan sebaiknya hadiah diberikan dengan digunakannya jadwal variabel Rasio rein forcer.

Dalam pembelajaran digunakan shaping.

b. Teori Nativist

1) Pengertian Tiori Nativist

Nativisme berasal dari kata Nativus yang berarti kelahiran. Teori ini muncul dari filsafat nativisma lahir sebagai suatu bentuk dari filsafat idealisme dan menghasilkan suatu pandangan bahwa perkembangan anak ditentukan oleh hereditas, pembawaan sejak lahir, dan faktor alam yang kodrati. Pelopor aliran ini adalah Arthur Schopen hauer seorang filosof Jerman yang hidup tahun 1788-1880 dan Noam Chomsky pada awal tahun 1960. Chomsky, mengatakan bahasa sudah ada di dalam diri anak.

2) Tokoh- tokoh Aliran Nativisme

a) Arthur Schopenhauer 
Dilahirkan di Danzig pada tanggal 22 Februari 1788. Schopenhauer dibesarkan oleh keluarga pembisnis. Ia berpendapat Pembawaanlah yang maha kuasa, yang menentukan perkembangan anak. Lingkungan sama sekali tidak bisa mempengaruhi, apalagi membentuk kepribadian anak. Perkembangan ditentukan oleh faktor pembawaannya, yang berarti juga ditentukan oleh anak itu sendiri

b. Immanuel Kant

Di lahirkan di Konigsberg pada 22 April 1724. Ia filsof Jerman dengan karyanya Kritik der Reinen Vernunft. Ia berpendapat bahwa :

Apa-apa yang bisa diketahui manusia hanyalah yang dipersepsi dengan panca indra. Lain daripada itu merupakan "ilusi" saja, hanyalah ide

Semua yang harus dilakukan manusia harus bisa diangkat menjadi sebuah peraturan umum. Hal ini disebut dengan istilah "imperatif kategoris". Contoh: orang sebaiknya jangan mencuri, sebab apabila hal ini diangkat menjadi peraturan umum, maka apabila semua orang mencuri, masyarakat tidak akan jalan.

Yang bisa diharapkan manusia ditentukan oleh akal budinya. Inilah yang memutuskan pengharapan manusia.

c) Gottfried Wilhemleibnitz

Gottfried Wilhemleibnitz adalah filsuf Jerman yang lahir di Leipzig, pada 1 Juli 1646. Gottfried mempunyai pandangan bahwa perkembangan manusia sudah ditentukan sejak lahir. Manusia hidup dalam keadaan yang sebaik mungkin karena dunian ini diciptakan oleh Tuhan. Chomsky kelahiran 1928, seorang ahli linguistic yang sangat terkenal hingga saat ini. Chomsky menganggap bahwa perkembangan penguasaan bahasa pada manusia tidak dapat dijelaskan semata-mata oleh proses belajar, tetapi juga (yang lebih penting) oleh adanya "biological predisposition" (kecenderungan biologis) yang dibawa sejak lahir. Aliran ini berpendapat bahwa perkembangan manusia ditentukan oleh faktorfaktor yang dibawa sejak lahir itulah yang menentukan perkembangannya dalam kehidupan. Dengan demikian menurut mereka pendidikan tidak membawa manfaat bagi manusia. Karena keyakinannya yang demikian itulah maka mereka di dalam ilmu pendidikan disebut juga aliran Pesimisme Paedagogi.

3. Tiori Constructiv

Tiori ini menyatakan menyatakan bahwa perkembangan kognisi dan bahasa dibentuk dari interaksi dengan orang lain sehingga pengetahuan, nilai dan sikap anak akan berkembang. Anak mempunyai perkembangan kognisi yang terbatas pada usia-usia tertentu, tetapi melalui interaksi sosial anak akan mengalami peningkatan kemampuan berpikir.

a) Teori Howard Gardner (1943)

Teori Howard Gardner muncul dalam jaman kita hidupsekarang ini. Ia mengatakan bahwa pada hakekatnya setiap anakadalah anak yang cerdas. Kecerdasan bukan hanya dipandang darifactor IQ saja, tetapi juga ada kecerdasan-kecerdasan lain yangakan mengantarkan anak pada kesuksesan. Macam-macam kecerdasan menurut Gardner adalah :1) Kecerdasan bahasa. Kecerdasan anak dalam mengelolakata-kata. 2) Kecerdasan logika. Kecerdasan dalam bidang angka danalasan logis. 3 )Kecerdasan musik. Kecerdasan dalam bidang musik.d. Kecerdasan gerak (kinestetik). Kecerdasan dalammengolah anggota tubuh.4) Kecerdasan gambar (spasial). Kecerdasan anak dalampermainan garis, warna, dan ruang. 5) Kecerdasan diri (intrapersonal). Kecerdasan dalam bidangpengenalan terhadap diri sendiri.6) Kecerdasan bergaul (interpersonal). Kecerdasan dalammembina hubungan dengan orang lain.7) Kecerdasan alami (naturalist). Kecerdasan yangberhubungan dengan alam.Kecerdasan rohani (spiritual). Kecerdasan mengolahrohani.

Gardner memandang bahwa setiap anak memiliki peluanguntuk belajar dengan gaya masing-masing anak.

b) John Bowlby (1907 - 1990).

John Bowlby terkenal adalah seorang pelopor teori Ethologi. Dia lahir di London. Dia merupakan seorang guru di Proggessive Schools for Children, yang memberi perawatan medis dan latihan psiko-analitik. Teori Bowlby yang tekenal adalah tentang teori attachment. Dia mengemukakan perkembang anattachment bayi. Attachment yang dimaksud adalah keteraturan,kesenangan, keinginan untuk melekat terhadap orang-orang yang diakrabi. Salah satu attachment bayi adalah menangis ketika ditinggal pengasuhnya dan tersenyum ketika pengasuhnya mendatanginya. Menurut Bowlby meskipun responsosial bayi pada awalnya tanpa diskrimisasi. Anak yang kehilangankesempatan untuk memperoleh hubungan sosial dengan orang lainakan mempengaruhi perkembangan sosial anak.Bila anak kehilangan kesempatan untuk megembangkan hubungan anak dengan lingkungan sosial selama periode bayi, maka 
mungkin hubungan sosial anak akan menjadi menyimpang seletah dewasa. Bayi yang kehilangan kontak yang memuaskan dengan manusia lain mereka akan kesulitan untuk mengembangkan tingah laku sosial yang sesuai. anak-anak yang sering ditinggal, petama anak akan menangis dan menolak semua bentuk pengasuhan, berkembang melalui periode despair; menjadi quiet,menarik diri dan pasif.. Pengasuh hendaknya memiliki pola yangtidak berbeda dengan orangtuanya.

\section{c) Jean Piaget (1907 - 1980)}

Istilah kognitif mulai banyak dikemukakan ketika teori-teori Jean Piaget banyak ditulis dan dibicarakan pada kira-kirapermulaan tahun 1960. Pengertian kognisis sebenarnya meliputi aspekaspek struktur intelek yang dipergunakan untuk mengetahui sesuatu. Piaget sendiri mengemukakan bahwa perkembangan kognitif bukan hanya hasil kematangan organisme, bukan pulapengaruh lingkungan saja, melainkan interaksi antara keduanya. Dalam psikologi kognitif, bahasa menjadi salah satu objekmaterialnya, karena bahasa merupakan perwujudan fungsi-fungsi kognitif.Piaget melihat adanya sistem yang mengatur dari dalam,sehingga organisme mempunyai sistem pencernaan, peredaran darah, pernapasan, dan lain-lain. Hal seperti ini juga terjadi dalam sistem kognisi, sistem yang mengatur di dalam yang kemudian dipengaruhi oleh faktor-faktor lingkungan. Sistem mengatur yang menetap terdapat sepanjang perkembangan seseorang.Perkembangan kognitif dengan demikian mempunyai 4 aspek yaitu :a. Kematangan. Kematangan ini merupakan pengembangan dari susunan syaraf. Misalnya kemampuan melihat atau mendengar disebabkan oleh kematangan yang sudah dicapai oleh susunan syaraf yang bersangkutan. b.Pengalaman, yaitu hubungan timbal balik antara organismedengan lingkungannya, dengan dunianya. c.Transmisi sosial, yaitu pengaruh-pengaruh yang diperolehdalam hubungannya dengan lingkungan sosial, misalnya carapengasuhan dan pendidikan dari orang lain yang diberikankepada anak. d.Ekuilibrasi, yaitu adanya kemampuan yang mengatur dalamdiri anak, agar ia selalu mampu mempertahankankeseimbangan dan penyesuaian diri terhadap lingkungannya.

Tahap-tahap perkembangan oleh Jean Piaget dibagi dalam masa-masa perkembangan sebagai berikut :1) Masa Sensori-motor (0-2 tahun) Masa ketika bayi mempergunakan sistem pengindraan dan aktivitas-aktivitas motorik untuk mengenal lingkungannya mengenal obyek-obyek. Contoh yang jelas dapat dilihat pada kemampuan bayi untuk menggerakkan otot-otot di sekitar mulut,gerakan mengenyot bilamana sedang menyusu. Jelas bahwa reflex yang diperlihatkan bayi bukan suatu kemampuan yang timbul darihasil belajar dalam hubungan dengan lingkungan melainkan sesuatu kemampuan yang sudah ada ketika bayi dilahirkan. Dengan berfungsinya alat-alat indera serta kemampuankemampuan melakukan gerakan motorik dalam bentuk refleks, bayi berada dalam keadaan siap untuk mengadakan hubungan dengan dunianya. 2) Masa Pra-operasional (2-7 tahun). Perkembangan yang jelas terlihat pada masa ini berbedadengan masa sebelumnya ialah kemampuan mempergunakansimbol. Fungsi simbolik, yakni kemampuan untuk mewakilkansesuatu yang tidak ada, tidak terlihat dengan sesuatu yang lain atausebaliknya sesuatu yang tidak ada. Fungsi simbolik ini bisa nyataatau abstrak. Dengan berkembangnya kemampuanmensimbolisasikan ini, anak memperluas ruang lingkupaktivitasnya yang menyangkut hal-hal yang sudah lewat, atau hal-hal yang akan datang, dan masa sekarang.Pada akhir masa pra-operasional, dasardasar pengelompokkan benda atas dasar sifat-sifat khusus dan benda-benda tersebut sudah bisa dilakukan, tetapi baru dengan satudimensi saja. Piaget mengatakan anak-anal pada masa praoperasional belum bisa memusatkan perhatian pada dua dimensi yang berbeda secara serempak. 3) Masa Operasional Konkrit / konkritoperasional (7-11 tahun) Pada masa ini anak-anak sudah mulai bisa melakukan bermacam-macam tugas, misalnya menyusun tongkat-tongkat, dan menjawab pertanyaan mengenai konservasi angka maupun isi dengan benar. Egosentrisme pada anak terlihat dari ketidak mampuannya untuk melihat pikiran dan pengalaman sebagai dua gejala yangmasing-masing berdiri sendiri. Dalam perkembangan kognitif lebih lanjut anak-anak akan mencapai kemampuan untuk berpikir dalam dua komponen, yakni pikirannya mengenai realitas dan realitasnya sendiri.d) Masa Operasional Formal / formal-operasional (dewasa) Masa ketika seorang anak memperkembangkan kemampuan kognitif untuk berpikir abstrak dan hipotesis. Pada masa ini anak bisa memikirkan hal-hal apa yang akan atau mungkin terjadi,sesuatu yang abstrak dan menduga apa yang terjadi. Piaget dengan teor- 
teorinya bermaksud menerangkan perkembangan kognisi pada anak-anak yang baru dilahirkan dan seterusnya lebih menghendakinya sebagai sumbangannya terhadap pengetahuan tentang kemanusiaan daripada sebagai penerapan teoriteorinya di dalam ruang kelas. Piaget menganggap hal belajarsebagai suatu proses yang aktif dan harus disesuaikan dengan tahap-tahap perkembangan anak. Belajar pada anak bukan sesuatu yang sepenuhnya bergantung pada guru.

d) Lev Vigotsky (1896 - 1934)

Vigotsky adalah seorang ahli perkembangan berkebangsaan Rusia. Teorinya disebut dengan teori belajar sosial. Vigotsky mengemukakan bahwa perkembangan manusia melalui interaksisosial yang memegang peranan penting dalam perkembangankognitif anak. Menurtut Vigotsky anak belajar melalui dua tahapanyaitu interkasi dengan orang lain, orang tua, saudara, teman sebaya,guru dan belajar secara individual melalui mengintegrasikan segalasesuatu yang dipelajari dari orang lain dalam struktur kognitifnya.Vigotsky mengemukakan tiga perlengkapan manusia yaitu tools ofthe minds, zone of proximal development dan scaffolding.Menurut Vigotsky kerja mental juga akan lebih mudah jikaada alat pendukungnya yang ia sebut sebagai tools of the minds yang berfungsi untuk mempermudah anak memahami suatufenomena, memecahkan masalah, mengingat, dan untuk berfikir. Misalnya, kelereng, buah-buahan, lidi, biji-bijian adalah sejenis alatyang dapat membantu anak memahami konsep bilangan. Melaluialat ini akan dapat menghubungkan benda dengan bahasa simbolik,seperti konsep bilangan satu, dua, tiga, empat, lima, dan enam.Konsep zone of proximal development adalah suatu konseptetang hubungan antara belajar dengan perkembangan anak. Istilahzone/zona menggambarkan bahwa perkembangan merupakan suatudaerah atau medan. Perluasan suatu medan perkembangan ditentukan oleh bantuan orang yang lebih ahli yang disebut scaffolding. Scaffolling adalah bantuan yang diperoleh anak dari seseorang yang lebih mampu, lebih mengetahui, dan lebih terampil dalam ZPD untuk membantu anak agar memperoleh hasil belajar yang lebih tinggi.Bentuk bantuan misalnya menyediakan objek, menunjukanbagian objek, menggunakan gambar, menunjukan cara menggunakan sesuatu atau memberikan alat bantu pengukuran.
Teori belajar Vigotsky memiliki empat prinsip umum yaitu: a. Anak mengkonstruksi pengetahuan akan lebih mudah bilatersedia tools of minds yang lebih kaya dan bervariasi,b. Belajar terjadi dalam kontek sosial. Oleh karena itu, untukmembantu mengoptimalkan perkembangan anak, dia harusdilibatkan sebanyak mungkin dalam interaksi sosial dengansebaya, guru, orang tua dan orang dewasa lainnya,c. Belajar mempengaruhi perkembangan mentald. Bahasa memegang peranan penting dalam membantuperkembangan mental anak.Oleh karena itu, untuk mengoptimalkan perkembangan berpikir anak, pengembangan bahasa atau literasi anak harus puladioptimalkan melalui melibatkan anak dalam aktivitas literasi dirumah, di lembaga PAUD dan di masyarakat.Vigotsky menyakini bahwa anak memiliki kemampuansecara aktif membagun pengetahuan melalui interaksi sosial dilingkungannya. Kontek sosial mempengaruhi perkembangan berpikir, sikap dan tingkah laku anak. Kontek sosial adalah meliputi seluruh lingkungan dimana anak tinggal yang secara langsung atau pun tidak langsung dipengaruhi oleh sistem budaya yang berlaku dalam masyarakat dimana anak hidup. Vogotsky mengemukakan tiga konteks sosial yaitu :a. Interaktif, orang lain atau teman sebaya yang sedang melakukan interaksi dengan anak .b. Tingkat struktural yaitu konteks sosial yang memiliki struktur seperti anggota keluarga, lembaga PAUD, dan masyarakat sekitar.

\section{Pengertian Bahasa}

Bahasa merupakan alat untuk berkomunikasi. Melalui bahasa manusia dapat berinteraksi dan berkomunikasi mengemukakan hasil pemikirannya dan dapat mengekspresikan perasaannya. Dengan bahasa orang dapat membuka cakrawala berfikir dan mengembangakan wawasannya. Anak-anak belajar bahasa melalui interaksi dengan lingkungannya baik lingkungan rumah,sekolah, atau masyrakat. Di sekolah anak belajar bahsa melalui interaksi dengan guru, teman sebaya dan orang dewasa lainnya. Menurut Fred Ebbeck (1989) bahasa dapat dimaknai sebagai suatu system tanda, baik lisan maupun tulisan merupakan system komunikasi antar manusia.Menurut Yus Badudu (1989) bahasa merupakan alat penghubung atau komunikasi antar anggota masyarakat yang terdiri dari individu-individu yang menyatakan perasaan, dan 
keinginannya. Bahasa sebagai suatu system lambing bekerja sama, berinteraksi, dan mengidentifikasikan diri. Lebih lanjut menurut Broomly mendefinisikan bahasa sebagai system simbol yang teratur untuk mentransfer berbagai ide maupun informasi yang terdiri dari simbolsimbol visual maupun verbal. Pendapat lain tentang bahasa dikemukakan oleh Eliason (1994) bahwa bahasa meliputi berbicara, menyimak,menulis dan ketrampilan membaca. Sedangkan menurut Hui Ling Chua (2003) bahasa memungkinkan anak untuk menterjemahkan pengalaman mentah ke dalam symbol-simbol yang dapat digunakan untuk berkomunikasi dan berfikir. Menurut Eliason, bahasa adalah alat untuk berfikir, mengekspresikan diri dan berkomunikasi.

\section{Kesimpulan}

Dari pembahasan di atas dapat disimpulkan bahwa, Teori belajar merupakan landasan terjadinya suatu proses belajar yang menuntun terbentuknya kondisi untuk belajar. Oleh karena itu dengan adanya teori-teori belajar maka akan memberikan kemudahan bagi guru dalam menjalankan model-model pembelajaran yang akan dilaksanakan dan akan membantu peserta didik dalam belajar.

Ada beberapa macam teori belajar yang muncul di dalam masa perkembangan psikologi pendidikan, diantaranya yaitu:

Teori behaviorisme

Teori kognitif, dan

Teori humanistik

Pendidikan anak usia dini pada dasarnya meliputi seluruh upaya dantindakan yang dilakukan oleh pendidik dan orang tua dalam prosesperawatan, pengasuhan dan pendidikan pada anak dengan menciptakanlingkungan yang kodusif dimana anak dapat mengeksplorasi dirinya ,memberikan kesempatan padanya untuk mengetahui dan memahamipengalaman belajar yang diperolehnya melalui lingkungan melalui caramengamati, meniru dan bereksperimen yang berlangsung secara berulang-ulang yang melibatkan seluruh potensi dan kecerdasan anak.

\section{Daftar Pustaka}

Budiningsih, C., Asri , (2005). Belajar dan Pembelajaran, Jakarta: PT Rineka Cipta.

Damayanti, Anita.( 2011). Hubungan Antara Keterampilan Membatik dan Motorik Halus Dengan Kemampuan Menulis Anak Usia 6-8
Tahun (Jurnal Pendidikan Anak Usia Dini). Jakarta: UN

Gage, N.L., \& Berliner, D. (1979).Educational Psychology.

Huberman,Michael dan Miles. (1992).Analisis Data Kualitatif .Jakarta:UIPress)

Moleong, Lexy. (2009). Metodologi Penelitian Kualitatif. Bandung: Remaja Rosdakarya

Wibowo, Agus. (2013).Pendidika Karakter Usia Dini. Yogyakarta: Pustaka Pelajar

Rachman, Maman.( 2011).Metode Penelitian Pendidikan Moraldalam Pendekatan Kuantitatif, Kualitatif, Campuran, Tindakan, dan Gage, N.L., \& Berliner, D. Educational Psychology.

Hall S. Calvin \& Lindzey, Gardner,(1993). Psikology kebribadian 3, Teori-Teori sifat dan behavioristik (diterjemahkan dari bukuTheories of personality, New york, Santa barbara Toronto, 1978), yogyakarta: Kanisius. 